\title{
ОСОБЛИВОСТІ ПРОЦЕСІВ ВІЛЬНОРАДИКАЛЬНОГО ОКИСНЕННЯ У ТКАНИНАХ ОРГАНІЗМУ В НОРМІ Й ПРИ ЗАСТОСУВАННІ ПОЛІСАХАРИДІВ
}

\author{
Особливості процесів вільнорадикального \\ окиснення у тканинах організму в нормі й при \\ застосуванні полісахаридів \\ О. М. Копаниця ${ }^{1}$, Н. В. Ліснянська ${ }^{2}$, П. І. Бучко ${ }^{3}$ \\ кзво «Рівненська медична академія» Рівненської \\ обласної ради \\ ВДНЗ «Буковинський державний медичний університет \\ мОЗ України»², Чернівці \\ Чортківський державний медичний коледж
}

Резюме. На сьогодні у світовій практиці в якості харчових добавок дозволено використовувати близько 500 різних речовин, нерахуючи величезної кількості різного роду ароматизаторів і деяких різновидів комбінованих добавок. Проте варто відмітити, що дані про фрізіологічну активність карагінанів, наявні в літературі, наведені в основному для комерційних зразків та в більшості своїй не враховують структурні особливості цих сульфратованих полісахаридів.

Мета дослідження - проаналізувати літературні джерела щодо особливостей перебігу процесів вільнорадикального окиснення в тканинах організму при застосуванні полісахаридів.

Матеріали і методи. У дослідженні опрацьовано наукові публікації за останнє десятиліття, які доступні у мережі «Інтернет», ключовими словами були «полісахариди», «карагінан», «вільнорадикальне окиснення».

Результати. На основі представлених літературних даних можна зробити висновок, що харчові добавки використовуються не тільки в харчовій, але й у косметичній, текстильній промисловостях, біотехнологічному виробництві тощо. Хоча харчові добавки, на думку багатьох науковців, не мають харчового значення, проте достеменно стверджувати про таку інертність харчових добавок, у тому числі й карагінану, щодо людського організму однозначно не можна. Відсутність канцерогенної, генотоксичної чи пухлинної активності карагінану, яку встановили науковці, дозволила у 2008 р. Експертному комітету з харчових добавок Всесвітньої організації охорони здоров'я рекомендувати не вказувати допустиму добову дозу цього полісахариду, хоча на даний час з'являються суперечливі дані. Деяка суперечливість даних про дію цих полісахаридів може бути зумовлена некоректним порівнянням результатів, отриманих в різних експериментальних умовах, на різних структурних

\author{
Peculiarities of free radical oxidation processes in \\ organism tissues in norm and in polysaccharides \\ usage \\ O. M. Kopanytsia ${ }^{1}$, N. V. Lisnianska ${ }^{2}$, P. I. Buchko ${ }^{3}$ \\ Rivne Medical Academy ${ }^{1}$ \\ Bukovinian State Medical University ${ }^{2}$ \\ Chortkiv State Medical College ${ }^{3}$
}

email: kopanycya651@ukr.net

Summary. Today in the world practice as a food additives allowed to use about 500 different substances, not counting the huge amount of different flavors and some varieties of combined additives. However, it should be noted that the available literature data on the physiological activity of carrageenans are given mainly for commercial samples and, for the most part, do not take into account the structural features of these sulfated polysaccharides.

The aim of the study - to analyze the literature on the features of the free radical oxidation processes in the tissues of the body when using polysaccharides.

Materials and Methods. The study looked at scientific publications over the last decade that are available on the Internet, with the ke ywords "polysaccharides", "carrageenan", "free radical oxidation".

Results. On the basis of the presented literature data we can conclude that food additives are used not only in food, but also in cosmetics, textile industry, biotechnological production and others. Although many scientists believe that nutritional supplements do not have nutritional value, it is certainly not possible to assert that such inertness of food supplements, including carrageenan, regarding the human body is unambiguous. The absence of carcinogenic, genotoxic or tumoral activity of carrageenan by scientists has allowed the Expert Committee on Nutritional Supplements of the World Health Organization to recommend not specifying a tolerable daily dose of this polysaccharide in 2008, although conflicting data are currently emerging. Some of the contradictory data on the effect of these polysaccharides may be due to incorrect comparison of the results obtained in different experimental conditions, with different structural types of carrageenans. It is very important that the method of administration of polysaccharide and its dose. 
типах карагінанів. При цьому дуже важливим є спосіб введення полісахариду і його доза.

Висновки. Аналітичний огляд основних тенденцій наукових досліджень вказує на потребу подальшого розширення і поглиблення уявлень про основні біохімічні процеси, що відбуваються при застосуванні карагінанів.

Ключові слова: полісахариди; карагінан; вільнорадикальне окиснення.

\section{ВСТУП}

Проблема здорового харчування надзвичайно актуальна в сучасному світі, оскільки біологічна роль компонентів їжі виступає не тільки як основне джерело пластичних та енергетичних ресурсів організму, але й полягає у забезпеченні речовин, які сприяють утворенню гормонів та ензимів - біологічних регуляторів обміну речовин у тканинах [1]. Проблема здорового харчування пов'язана, насамперед, з недостатньою поінформованістю населення про склад харчових продуктів (їх екологічну якість), оскільки поруч з необхідними поживними харчовими речовинами до складу їжі можуть входити різні за хімічною природою сполуки неаліментарного характеру, що не мають харчової цінності, й, більш того, шкідливі та потенційно небезпечні для здоров'я людини [2, 3]. У даний час досліджують безліч різних продуктів харчування, їх склад, наявність харчових добавок, їх шкідливість. Для покращення органолептичних властивостей або ж для досягнення відповідного технологічного ефекту до харчових продуктів часто додають харчові добавки, які можуть бути хімічної або біологічної природи. Харчові добавки використовують для збереження, продовження терміну придатності продуктів, які ми споживаємо $[4,5]$.

На сьогодні у світовій практиці в якості харчових добавок дозволено використовувати близько 500 різних речовин, нерахуючи величезної кількості різного роду ароматизаторів і деяких різновидів комбінованих добавок [6]. У США кількість харчових добавок перевищує 1500, в країнах Європейського союзу досягає 1200, в Росії - 415 [7]. До початку 90-х років XX ст. їх вживання в Україні було обмеженим порівняно із зарубіжними країнами Європи та США [8]. Так, до 1994 р. було дозволено лише 194 харчових добавок, а вже згідно з Постановою Кабінету Міністрів у 2000 р. - 221. Крім того, в країнах Європейського Союзу дозволено використовувати в харчовому виробництві більш як 400 ароматизаторів та смакових речовин. Відповідно до системи «Codex Alimentarius», класифрікація харчових добавок здійснюється за їх призначенням. Розрізняють 30 функціональних класів харчових добавок, серед яких консерванти, антиоксиданти, підсолоджувачі, барвники, загусники,
Conclusions. Analytical review of the main trends of scientific research indicates the need to further expand and deepen the understanding of the basic biochemical processes that occur when applying carrageenans.

Key words: polysaccharides; carrageenan; free radical oxidation.

емульгатори, желюючі речовини, стабілізатори, посилювачі смаку, регулятори кислотності (буфери), розпушувачі, модифріковані крохмалі та інші [9, 10]. Варто відзначити, що для деяких харчових добавок в Україні встановлено жорсткіші нормативи, ніж у законодавстві Європейського Союзу, що підтверджує необхідність перегляду й наукового обґрунтування цих нормативів [11].

Полісахариди як харчові компоненти є біологічно активними речовинами, що мають виражену фрізіологічну дію. Окрім резервних полісахаридів, що розщеплюються фрерментами шлунково-кишкового тракту людини та виконують енергетичну фрункцію, існує велика кількість інших, які не здатні до гідролізу під дією травних ферментів. До таких відносяться целюлоза, ксилани, манани, арабінани, галактани, галактуронани тощо. Сировинними джерелами таких полісахаридів $€$ різноманітні вищі рослини (фрукти, овочі, дерева, трави), водорості, гриби, ракоподібні, деякі тканини тваринного походження, мікроорганізми. В харчових цілях і в медичній практиці також важливе місце посідає харчова добавка, яку виділяють водною екстракцією з морських водоростей - карагінан [12]. Для медичної практики карагінан застосовують для створення систем 3 контрольованим вивільненням активних речовин, що забезпечують пролонгування необхідної концентрації діючої речовини і поліпшують біодоступність лікарського препарату [13, 14]. Широке застосування карагінанів у косметології зумовлене включення його до складу кремів і зубних паст для покращення фрізико-хімічних властивостей [15]. Експертний комітет із харчових добавок ФАО/ВООЗ встановив допустиму добову дозу карагінану - до 75 мг на 1 кг маси тіла. Дослідники експериментально вважають, що для гелів солодких страв забезпечення необхідної міцності структури їх можливе за умови використання каппа-карагінану за концентрації 0,6 \%, а для гелів для солоних страв - каппакарагінану при концентрації 0,8 \% [16]. Варто відмітити, що наявні літературні дані про фрізіологічну активність карагінанів наведені в основному для комерційних зразків та в більшості своїй не враховують структурні особливості цих сульфратованих полісахаридів. 
Метою дослідження було проаналізувати літературні джерела щодо особливостей перебігу процесів вільнорадикального окиснення в тканинах організму при застосуванні полісахаридів.

\section{МАТЕРІАЛИ I МЕТОДИ}

У дослідженні опрацьовано наукові публікації за останнє десятиліття, що доступні у мережі «اнтернет», ключовими словами були «полісахариди», «карагінан», «вільнорадикальне окиснення».

\section{РЕЗУЛЬТАТИ ТА ОБГОВОРЕННЯ}

Відомо, що в живому організмі постійно відбуваються реакції, пов'язані з участю так званих активних кисневих метаболітів. Активні фрорми оксигену (АФО) генеруються як у фрізіологічних умовах, так і при ряді патологічних станів, як наприклад, при гіпоксії, ішемії-реперфузії, гіпероксії, при дисфрункції мітохондрій, в реакціях Фентона, при ушкодженні ендотелію, метаболізмі ненасичених жирних кислот. Їх дія може зумовлювати деструкцію мембран і ушкодження клітин при недостатній активності антиоксидантної системи захисту. В умовах, коли при споживанні карагінанів розвивається хронічний ентероколіт (ХЕК), відмічають оксидативний стрес, що проявляється зниженням активності ензимів дихального ланцюга в клітинах слизової оболонки кишки, гіперпродукцією АФО і продуктів їх окиснення у різних біологічних матеріалах. Тому сьогодні у наукових працях досліджується роль мітохондріальної диссрункції і оксидативного стресу при фрормуванні патогенетичного каскаду ХЕК, викликаного карагінаном.

У біологічних системах можна виділити кілька типів вільних радикалів (ВР). Одні з них утворюються в якості фрізіологічних продуктів обміну речовин, який нормально перебігає, інші виникають при зміні умов життєдіяльності. У числі останніх ВР води й органічних молекул, що утворюються при дії на клітину іонізуючих і ультрафріолетових випромінювань, різних токсичних речовин, а також при багатьох захворюваннях [17]. Процеси вільнорадикального окиснення за участю АФО при досить низькій інтенсивності належать до нормальних метаболічних процесів [18]. Вільнорадикальні процеси відбуваються за будь-якої патології, причому кожному захворюванню властиві закономірні й характерні зміни їх інтенсивності. Різноманіття біохімічних реакцій великою мірою зумовлюється здатністю ВР при взаємодії з різними речовинами перетворювати їх також у ВР [19]. У зв'язку з цим особливе значення мають ланцюгові реакції - xiмічні процеси, що відбуваються за участю ВР. Каталізаторами таких реакцій можуть бути як кінцеві, так і проміжні їх продукти. Якщо в ході ланцюгової реакції зустрічаються два ВР, то реакційний ланцюг обривається, так як радикали, взаємодіючи між собою, утворюють валентнонасичену молекулу, нездатну продовжувати ланцюг. Водночас, скільки б разів не відбувалися реакції ВР із нейтральними молекулами, кількість радикалів не зміниться, що відповідає відомому в хімії принципу незнищенності вільної валентності. Швидкість ланцюгового процесу буде залежати як від кількості утворених ВР, так і від кількості зруйнованих радикалів, точніше кажучи, від співвідношення цих показників. Ось чому можна пришвидшити ланцюговий процес додаванням речовин, що містять ВР, або самим шляхом впливу деяких фізичних фракторів і різноманітних речовин (наприклад харчових добавок), здатних індукувати утворення цих проміжних сполук [20]. Радикали кисню індукують процеси пероксидного окиснення ліпідів (ПОЛ), необхідні для процесів оновлення фоосфоліпідів i регуляції проникності клітинних мембран. Важливою фрізіологічною функцією АФО є активація ряду мембранних білків і імуноглобулінів, а також фрерментів, що регулюють перемикання метаболічних шляхів і синтез макроергічних з'єднань у клітині. 3 процесами ВРО безпосередньо пов'язане окисне фоссрорилування і швидкість клітинного ділення [21]. Гідрогену пероксид може виступати в якості метаболічного сигналу для внутрішньоклітинних процесів, що призводять до окиснення специфічних SH-груп протеїнкіназ. Будучи активованими, ці білки транслокуються в ядро й індукують експресію групи генів, продукти експресії яких відповідають за різні форми захисних реакцій клітини. Така дволикість властивостей активізованих метаболітів оксигену зумовлює динамічну рівновагу між продукцією ВР і їх нейтралізацією у фізіологічних умовах [22-24], а також різні 3 організації механізми ії підтримки.

Результати аналізу сучасної літератури дозволяють стверджувати, що зусилля багатьох досліджень у різних країнах сьогодні сконцентровані на вивченні полісахаридів і екстрактів водоростей як джерел природних антиоксидантів і можливості використання їх в якості гепатопротекторів. Необхідність даних досліджень визначається такими факторами. По-перше, імуномодулюючий [25, 26], гіполіпідемічний [27], сорбуючий [28] вплив водоростей і отриманих із них полісахаридів на фуннціонування шлунково-кишкового тракту, а також на печінку, яка відіграє центральну роль у метаболічних процесах організму. По-друге, відомі роботи про гіпоглікемічну [29], антиоксидантну [30], детоксикаційну [31] дії сульфратованих полісахаридів, в реалізації яких беруть участь ферменти і метаболіти, утворені печінкою. Вчені встановили потенційну антиоксидантну активність усіх досліджуваних сульсратованих полісахаридів, що проявляється в здатності захоплювати монооксиду нітроген, гідроксил-радикал, супероксид-аніон. 
Антиоксидантна активність їх зменшується зі збільшенням $\mathrm{pH}$, залежить від моносахаридного складу, кількості й розташування сульфатних груп у полісахаридах і не пов'язана з їх відновлювальною здатністю [32].

У патогенезі інтоксикації гепатоцитів ключову роль відіграє оксидативний стрес, який характеризується порушенням обміну речовин і енергії, накопиченням активних ушкоджувальних агентів (ВР, прооксидантів, АФО), що ініціюють патологічні зміни в клітинах і ведуть до розвитку різних патологічних станів [33]. Основний негативний ефект ВР полягає в ушкодженні мембран клітин, модифрікації білків РНК і ДНК. В якості медикаментозної терапії на усіх етапах і при усіх фрормах ураження печінки використовують антиоксиданти, які на сьогодні розглядаються як профрілактичні засоби в лікуванні печінки [34]. В останні роки чітко показано, що сульфатовані полісахариди відіграють важливу роль у попередженні розвитку оксидативного стресу живих організмів [35], завдяки можливості захоплювати супероксидні радикали, а також інгібувати взаємодію між металами і ліпідами через утворення нерозчинних комплексів з іонами феруму або генерацією стеричних перешкод [36]. Антиоксидантна активність сульоратованих полісахаридів, до яких відноситься карагінан, пов'язана не тільки 3 молекулярною масою і наявністю сульфатних груп, але і з наявністю глюкуронової кислоти, фрруктози і нейтральних цукрів [37]. Для карагінанів характерна фрерумредукуюча здатність й інгібуюча дія на гідроксил- і супероксиданіон радикали. Вони посилюють каталітичну активність СОД, каталази. Проте як зазначають вчені, тільки на перших етапах ушкодження клітин, тобто в гострій фразі, вистачає антиоксидантних фрерментів для нейтралізації накопичених АФО, при подальшому прогресуванні процесу ще більше підвищення їх активності вже недостатньо для компенсації збільшеної генерація АФО. В даному випадку ступінь активності карагінану залежить від дозування і тривалості прийому, але також важливе місце має його структура [38].

Відомо, карагінан є потужним індуктором запалення, а ступінь токсичності залежить від молекулярної маси біополімера і кількості залишків сірчаної кислоти [39, 40]. Чим вище рівень сульфатування, тим більше виражена здатність карагінану індукувати запальний процес. Напри-

\section{СПИСОК ЛІТЕРАТУРИ}

1. Олексієнко Я. І. Харчування та його вплив на здоров'я людини: навчально-методичний посібник / Я. І. Олексієнко, В. А. Шахматова, О. П. Верещагіна. Черкаси : ПП Чабаненко Ю. А., 2014. - 42 с.

2. Савочкина И. В. Пищевые добавки, применяемые клад, тривале пероральне вживання $\lambda$-карагінану, який характеризується високим ступенем сульфатування, здатне приводити до розвитку інтерстиціального запалення, яке підтверджується морорологічно і біохімічно $[41,42]$. Вчені довели, що при чотиритижневому безперервному вживанні карагінану відбувається зростання інтенсивності вільнорадикального окиснення і перш за все пероксидного окиснення ліпідів (ПОЛ), яке сприяє розвитку різних патологічних процесів, що чітко проявляються в ентероцитах кишечника. Найінформативнішими показниками наявності активації поЛ є ТБК-активні продукти. Встановлено, що при гастроентероколіті, спровокованому вживанням карагінану, зростає рівень ТБК-активних продуктів, концентрація ДК. Дані результати свідчать про активацію вільнорадикальних процесів, що зумовлено генерацією АФО, і процесів ліпідної пероксидації. Відомо, що генерація АФО ентероцитами кишечника стимулюється безпосередньо карагінаном [43], що може свідчити про значну роль вільнорадикальних процесів в ініціації запалення при колітах $[44,45]$.

\section{ВИСНОВкИ}

1. Харчові добавки використовуються не тільки в харчовій, але й у косметичній, текстильній промисловостях, біотехнологічному виробництві тощо. Хоча харчові добавки, на думку багатьох науковців, не мають харчового значення, проте достеменно стверджувати про таку інертність їх, у тому числі й карагінану, щодо людського організму однозначно не можна. Відсутність канцерогенної, генотоксичної чи пухлинної активності карагінану, яку встановили науковці, дозволила у 2008 р. Експертному комітету з харчових добавок Всесвітньої організації охорони здоров'я рекомендувати не вказувати допустиму добову дозу цього полісахариду, хоча на даний час з'являються суперечливі дані. Це може бути зумовлено некоректним порівнянням результатів, отриманих в різних експериментальних умовах, на різних структурних типах карагінанів. При цьому дуже важливим $€$ спосіб введення полісахариду і його доза.

2. Аналітичний огляд основних тенденцій наукових досліджень вказує на потребу подальше розширити і поглибити уявлення про основні біохімічні процеси, що відбуваються при застосуванні карагінанів. 
3б. наук. праць співробіт. НМАПО імені П. Л. Шупика. 2013. - № 22(4). - C. 467-473.

4. Мазараки А. А. Технологія продуктів фрункціонального призначення / А. А. Мазараки, М.І.Пересічний, М. Ф. Кравченко. - К. : Київ. нац. торг. екон. ун-т, 2012. -1116 c.

5. Вся правда о пищевых добавках. ИнтернетКаталог продуктов питания: сайт. URL: http://www. goodsmatrix.ru/articles/Vsja-pravda-o-piwevyhdobavkah. html (дата звернення: 22.03. 2015).

6. Нечаев А. П. Пищевые добавки : учеб. А. П. Нечаев, А. А. Кочеткова, А. Н. Зайцев. - М. : Колос, 2001. $-256 \mathrm{c}$.

7. Technical Regulations of the Customs Union TR TS 029/2012 "Safety of food additives, flavorings and processing aid means" (decision of the Council of the Eurasian Economic Commission no. 58 of July 20, 2012). URL:http://www.eurexcert.com/TRCUpdf/TRCU029Safetyr equirementsoffoodadditives.pdf.

8. Смоляр В. І. Сучасні проблеми використання харчових добавок / В. І. Смоляр // Проблеми харчування. - 2009. - C. 5-13.

9. Смоляр В. І. Токсичні ефекти харчових добавок / В. І. Смоляр // Проблеми харчування. - 2005. - № 1. C. 5-15.

10. USP Food Chemicals Codex: FCC 7; [2010-2011] (7th ed.). Rockville, MD: The United States Pharmacopeial Convention, 2010. URL : https://books.google.com.ua/books ?id=zNr3YaoNZvQC\&pg=PP1\&lpg=PP1\& ...Codex\&f=false.

11. Адамчук Т. В. Санітарні заходи щодо харчових добавок, ароматизаторів та ензимів. Ризики для здоров'я у контексті змін, внесених до Законодавства України / Т. В. Адамчук, Н. Є. Чумак // Довкілля і здоров'я. -2016. - № 3. - С. 68-74.

12. Comparison of the structures of hybrid $\mathrm{k}-/ \beta$ carrageenans extracted from Furcellaria lumbricalis and Tichocarpus crinitus / G. Correca, A. Barabanova, R. Tuvikene [et al.] // Carbohyd. Polym. - 2012. - Vol. 88. - P. 31-36.

13. Keppeler S. Cross-linked carrageenan beads for controlled release delivery systems / S. Keppeler, A. Ellis, J. C. Jacquier // Carbohydr. Polym. - 2009. - Vol. 78. P. 973-977.

14. Yermak I. M. Chemical properties, biological activities and applications of carrageenan from red algae / I. M. Yermak, Y. S. Khotimchenko // Recent Advances in Marine Biotechnology. - 2003. - Vol. 23. - P. 207-255.

15. Подобій О. Вплив карагінану на фрізико-хімічні властивості зубних паст / О. Подобій, М. Ладонько // Актуальні проблеми хімії та хімічної технології : матеріали II Всеукраїнської наук.-практ. конср. (м. Київ, 21-23 лист. 2016 р.). - К., 2016. - С. 299-300.

16. Мартинов С. В. Застосування каппа-карагінану у складі харчових продуктів / С. В. Мартинов, Т. І. Маренкова // Матеріали наук. конф. студентів Сумського НАУ (м. Суми, 17-19 лист. 2015 р.). - Суми, 2015. - Т. ІІІ. - С. 182.

17. Зуйков С. А. Исследование соотношения прооксидантной и антиоксидантной систем при опухолях кишечника / С. А. Зуйков, Б. Г. Борзенко, О.В.Зуйкова // Сибирский онкологический журнал. - 2014. - № 2 (62). - C. 24-27.

18. Yin D. The essential mechanisms of aging: What have we learnt in ten years? / D. Yin // Current Topics in
Medicinal Chemistry. - 2016. - Vol. 16. - No. 5. - P. 503510.

19. Мартусевич А. К. Антиоксидантная терапия: современное состояние, возможности и перспективы / А. К. Мартусевич, К. А. Карузин, А. С. Самойлов // Биорадикалы и антиоксиданты. - 2018. - Т. 5, № 1. - С. 5-23.

20. Окислительный стресс. Прооксиданты и антиоксиданты / Е. Б. Меньщикова, В. 3. Ланкин, Н. К. Зенков [и др.]. - М. : Слово, 2006. - 556 с.

21. Free radicals and antioxidants in normal physiological functions and human disease / M. Valko, D. Leibfritz, J. Moncol [et al.] // Intern. J. Biochem. Cell. Biol. - 2007. - Vol. 39. - No. 1. - P. 44-84.

22. Sohal R. S. Role of oxidative stress and protein oxidation in the aging process / R. S. Sohal // Free Radic. Biol. Med. - 2002. - Vol. 33. - No. 1. - P. 37-44.

23. Assessment of antioxidant activity by using different in vitro methods / K. Schlesier, M. Harwat, V. Böhm [et al.] // Free Radical Res. - 2002. - Vol. 36. - No. 2. - P. 177-178.

24. Is the of specialized nutritional formulations a cost-effective strategy? A national database evaluation / A. Strickland, A. Brogan, J. Krauss [et al.] // J. Parenter. Enteral. Nutr. - 2005. - Vol. 29 (1 Suppl.). - P. 81-91.

25. Имунотропные и антикоагулянтные свойства фрукоидана из бурой водоросли Fucus evanescens: переспективы применения в медицине / Н. Н. Беседнова, Н. М. Шевченко, Т. П. Смолина [и др.] // Журнал микробиологии. - 2006. - № 3. - С. 54-58.

26. Кузнецова Т. А. Приминение фукоидана из бурой водоросли Fucus evanescens для коррекции нарушения иммунитета и гемостаза на модели эндотоксемии / Т. А. Кузнецова // Бюлл. эксп. биол. и мед. - 2009. T. 147, № 1. - C. 71-74.

27. Hypolipidemic effect of fucoidan from Laminaria japonica in hyperlipidemic rats / L. Huang, K. Wen, X. Gao [et al.] // Pharmaceutical Biology. - 2010. - Vol. 48. No. 4. - P. 422-426.

28. Хотимченко М. Ю. Сорбционные свойства и фармаколо-гическая активность некрахмальных полисахаридов : автореф. дисс. на соискание уч. степени д-ра биол. наук : спец. 14.03.06. / М. Ю. Хотимченко. Владивосток, 2011. - 46 с.

29. Влияние иммуномодулятора фрукоидана из бурой водоросли Fucus evanescens на показатели антиоксидантной системы, липидного и углеводного обмена у мышей / К. В. Майстровский, Т. С. Запорожец, Л. Н. Федянина [и др.] // Тихоокеан. мед. журн. - 2009. № 3. - Р. 97-99.

30. Chemical characterization and antioxidant activity of sulfated polysaccharide from the red seaweed Gracilaria birdiae / W. S. S. Bartolomeu, M. A. Cerqueira, A. I. Bourbon [et al.] // Food Hydrocolloid. - 2012. - Vol. 27, No. 2. P. 287-292.

31. Abd El Baky H. H. Healthy benefit of microalgal bioactive substances / H. H. Abd El Baky, G. S. El-Baroty // J. Aquatic. Sci. - 2013. - Vol. 1, No. 1. - P. 11-23.

32. In vitro antioxidant properties of red algal polysaccharides / E. V. Sokolova, A. O. Barabanova, R. N. Bogdanovich [et al.] // Biomed. Preven. Nut. - 2011. Vol. 1, No. 3. - P. 161-167.

33. Oxidative stress and hepatitis $\mathrm{C}$ virus I U. Z. Paracha, K. Fatima, M. Alqahtani [et al.] // Virology Journal. - 2013. - Vol. 10. - P. 251-258. 
34. Algae: a potent antioxidant source / N. Munir, N. Sharif, S. Naz [et al.] // Sky. J. Microbiol. Res. - 2013. Vol. 1, No. 3. - P. 22-31.

35. Assessment of antioxidant activity, total phenolic content and in vitro toxicity of Malaysian red seaweed Acanthophora specifera / A. N. Zakaria, D. Ibrahim, S. F. Sulaiman [et al.] // Chem. Pharm. Res. - 2011. Vol. 3, No. 3. - P. 182-191.

36. Costa L. S. Heterofucan from Sargassum filipendula induces apoptosis in HeLa cells / L. S. Costa, C. B. S. Telles, R. M. Oliveira // Mar. Drugs. - 2011. - Vol. 9, No. 4. P. 603-614.

37. Biologically active compound in seaweed extracts the prospects for the application / K. Chojnacka, A. Saeid, Z. Witkowska [et al.] // The Open Conf. Proceed. J. - 2012. - Vol. 3. - Suppl. 1-M4. - P. 20-28.

38. Изучение in vitro и ex vivo антиоксидантной активности каррагинанов - сульфатированных полисахаридов красных водорослей / Е. В. Соколова, А. О. Барабанова, В. А. Хоменко [и др.] // Бюлл. эксп. биол. и мед. - 2010. - № 10. - C. 398-401.

39. Krynytska I. The indices of nitric oxide system in rats with carrageenan-induced enterocolitis combined with diabetes mellitus / I. Krynytska, M. Marushchak // Romanian Journal of Diabetes Nutrition and Metabolic Diseases. 2018. - No. 25 (3). - P. 283-288.

40. The indices of endogenous intoxication in rats with carrageenan solution consumption / I. Krynytska,

\section{REFERENCES}

1. Oleksiyenko YI, Shakhmatova VA, Vereshchagina OP. Nutrition and its impact on human health: a textbook. [Xapчування та його вплив на здоров'я людини: навчальнометодичний посібник] Cherkasy: PP Chabanenko Yu. A. 2014. Ukrainian

2. Sost. IV Savochkina. Nutritional supplements used in catering study guide. [Савочкина И. В. Пищевые добавки, применяемые в общественном питании учебное пособие] Bryansk: Michurinskiy filial FGBOU VO Bryanskiy GAU. 2015. Russian.

3. Kozyarin IP, Ivakhno OP. [Effect of anti-nutritional factors of food on human health]. Zb. nauk. prats spivrobit. NMAPO imeni P.L. Shupyka. 2013; 22(4): 467-73. Ukrainian.

4. Mazaraki AA, Peresichny MI, Kravchenko MF. Functional products technology. [Технологія продуктів фрункціонального призначення] Kyiv: Kyiv. nats. torh. ekon. un -t. 2012. Ukrainian.

5. The truth about food additives Available from: http:// www.goodsmatrix.ru/articles

6. Nechaev AP, Kochetkova AA, Zaitsev AN. Food additives: textbook. [Пищевые добавки: учеб] Moscow: Kolos; 2001. Russian.

7. Technical Regulations of the Customs Union TR TS 029/2012 "Safety of food additives, flavorings and processing aid means" (decision of the Council of the Eurasian Economic Commission no. 58 of July 20, 2012). Available from: http://www.eurexcert.com/TRCUpdf/TRCU0 29Safetyrequirementsoffoodadditives.pdf.

8. Smolyar VI. [Modern problems of using food supplements]. Problemy kharchuvannia. 2009; 5-13. Ukrainian.
M. Marushchak, O. Svan [et al.] // Georgian Medical News. - 2018. - P. 196-200.

41. Ткаченко А. С. Особливості білкового спектра і цитокінового складу сироватки крові щурів при хронічному карагенан-індукованому інтестинальному запаленні / А. С. Ткаченко, Т. В. Горбач, О. М. Пономаренко // Актуальні питання фрармацевтичної і медичної науки та практики. - 2014. - № 1 (14). - С. 73-75.

42. Damage and regeneration of small intestinal enterocytes under the influence of carrageenan induces chronic enteritis / G. I. Gubina-Vakyulyk, T. V. Gorbach, A. S. Tkachenko [et al.] // Comparative Clinical Pathology. 2015. - Vol. 24, No. 6. - P. 1473-1477.

43. Bhattacharyya S. Carrageenan-induced NF kappa $B$ activation depends on distinct pathways mediated by reactive oxygen species and $\mathrm{Hsp} 27$ or by $\mathrm{Bcl} 10$ / S. Bhattacharyya, P. K. Dudeja, J. K. Tobacman // Biochim. Biophys. Acta. - 2008. - Vol. 1780, No. 7-8. - P. 973-982.

44. Копаниця О. М. Метаболічні процеси у стінці тонкої кишки, серці й печінці при експериментальному застосуванні карагінану / О. М. Копаниця, М. І. Марущак, А. А. Щербатий // Медична та клінічна хімія. - 2017. T. 19, № 3 (72). - C. 108-113.

45. Пероксидне окиснення білків стінки тонкої кишки, міокарда та печінки щурів при експериментальному застосуванні карагінану / М. І. Марущак, О. М. Копаниця, І. Я. Криницька [и др.] // Медична та клінічна хімія. - 2017. - Т. 19, № 4 (73). - С. 109-114.

9. Smolyar VI. [Toxic effects of food additives]. Problemy kharchuvannia. 2005;1: 5-15. Ukrainian.

10. USP Food Chemicals Codex: FCC 7; [2010-2011] (7th ed.). Rockville, MD: The United States Pharmacopeial Convention. 2010; Available from: https://books.google. com.ua/books?id=zNr3YaoNZvQC\&pg=PP1\&lpg=PP1\&... Codex\&f=false.

11. Adamchuk TV, Chumak NE. [Sanitary measures for food additives, flavors and enzymes. Health risks in the context of changes made to the Legislation of Ukraine]. Dovkillia i zdorovia. 2016;3: 68-74. Ukrainian.

12. Correc G, BarabanovaA, Tuvikene R, Truus K, Yermak I, William Helbert W. Comparison of the structures of hybrid $\mathrm{K}$-/ $\beta$-carrageenans extracted from Furcellaria lumbricalis and Tichocarpus crinitus. Carbohyd. Polym. 2012;88: 31-6.

13. Keppeler S, Ellis A, Jacquier JC. Cross-linked carrageenan beads for controlled release delivery systems. Carbohydr Polym. 2009;78: 973-7.

14. Yermak IM, Khotimchenko YS. Chemical properties, biological activities and applications of carrageenan from red algae. Recent Advances in Marine Biotechnology. 2003;23: 207-55.

15. Podobiy O, Ladonko M. [Effect of carrageenan on the physicochemical properties of toothpastes]. Aktualni problemy khimii ta khimichnoi tekhnolohii: materialy II Vseukrainskoi nauk.-prakt. konf. (Kyiv, November, 21-23). 2016; 299-300. Ukrainian.

16. Martynov SV, Marenkova TI. [Application of kappacarrageenan in food composition]. Materialy nauk. konf. studentiv Sums'koho NAU (Sumy, November 17-19). 2015; III. 182. Ukrainian. 
17. Zuikov SA, Borzenko BG, Zuikova OV. [Investigation of the ratio of prooxidant and antioxidant systems in intestinal tumors]. Sibirskiy onkologicheskiy zhurnal. 2014;2(62): 247. Russian.

18. Yin D. The essential mechanisms of aging: What have we learnt in ten years? Current Topics in Medicinal Chemistry. 2016;16(5): 503-10.

19. Martusevich AK, Karuzin KA, Samoilov AS. [Antioxidant therapy: current status, capabilities and prospects]. Bioradikaly i antioksidanty. 2018;5(1): 5-23. Russian.

20. MenshchikovaEB, Lankin VZ, Zenkov NK, Cooper IA, Krugovyh NF, Trufakin VA. [Oxidative stress. Prooxidants and antioxidants]. Moscow: Slovo; 2006. Russian.

21. Valko M, Leibfritz D, Moncol J, Cronin MT, Mazur M, Telser J. Free radicals and antioxidants in normal physiological functions and human disease. Intern. J Biochem Cell Biol. 2007;39(1): 44-84.

22. Sohal RS. Role of oxidative stress and protein oxidation in the aging process. Free Radic Biol Med. 2002;33(1): 37-44.

23. Schlesier $K$, Harwat $M$, Böhm V, Bitsch R. Assessment of antioxidant activity by using different in vitro methods. Free Radical Res. 2002;36(2): 177-8.

24. Strickland A, Brogan A, Krauss J, Martindale R, Cresci G. Is the of specialized nutritional formulations a cost-effective strategy? A National Database Evaluation. J Parenter Enteral Nutr. 2005;29(1): 81-91.

25. Besednova NN, Shevchenko NM, Smolin TP, Kuznetsova TA, Zaporozhets TS, Zvyagintsev TN. [Imunotropic and anticoagulant properties of fucoidan from brown alga Fucus evanescens: prospects for use in medicine]. Zhurnal mikrobiologii. 2006;3: 54-8. Russian.

26. Kuznetsova TA. [Use of fucoidan from brown alga Fucus evanescens to correct impaired immunity and hemostasis in an endotoxemia model]. Byull eksp biol i med. 2009;147(1): 71-4. Russian.

27. Huang L, Wen K, Gao X, Liu Y. Hypolipidemic effect of fucoidan from Laminaria japonica in hyperlipidemic rats. Pharmaceutical Biology. 2010; 48(4): 422-6.

28. Khotimchenko MYu. Sorption properties and pharmacological activity of non-starch polysaccharides. Doctor's thesis. Vladivostok;2011. Russian.

29. Maistrovsky HF, Fedyanina LN, Zaporozhets TS, Kalenik TK, Motkina EV. [The effect of the immunomodulator fucoidan from brown alga Fucus evanescens on the performance of the antioxidant system, lipid and carbohydrate metabolism in mice]. Tikhookeanskiy med zhurnal. 2009;3: 97-9. Russian.

30. Bartolomeu WSS, Cerqueiraa MA, Bourbona Al, Pinheiroa AC, Martinsa JT, Teixeiraa JA, Coimbra MA, et al. Chemical characterization and antioxidant activity of sulfated polysaccharide from the red seaweed Gracilaria birdiae. Food Hydrocolloid. 2012;27(2): 287-92.

31. Abd El Baky HH, El-Baroty GS. Healthy benefit of microalgal bioactive substances. J Aquatic Sci. 2013;1(1): 11-23.
32. Sokolova EV, Barabanova AO, Bogdanovich RN, Khomenko VA, Solov'eval TF, Yermak M. In vitro antioxidant properties of red algal polysaccharides. Biomed Preven Nut. 2011;1(3): 161-7.

33. Paracha UZ, Fatima K, Alqahtani M, Chaudhary A, Abuzenadah A, Damanhouri G, Qadri I. Oxidative stress and hepatitis C virus. Virology Journal. 2013;10: 251-8.

34. Munir N, Sharif N, Naz S, Manzoor F. Algae: a potent antioxidant source. Sky J Microbiol Res. 2013;1(3): 22-31.

35. Zakaria AN, Ibrahim D, Sulaiman SF, Supardy NA. Assessment of antioxidant activity, total phenolic content and in vitro toxicity of Malaysian red seaweed Acanthophora specifera. Chem Pharm Res. 2011;3(3): 182-91.

36. Costa LS, Telles CBS, Oliveira RM. Heterofucan from Sargassum filipendula induces apoptosis in HeLa cells. Mar Drugs. 2011;9(4): 603-14.

37. Chojnacka K, Saeid A, Witkowska Z, Tuhy L. Biologically active compound in seaweed extracts - the prospects for the application. The Open Conf Proceed J. 2012;3(1-M4): 20-8.

38. Sokolova EV, Barabanova AO, Khomenko VA, Soloviev TF, Bogdanovich LV. [In vitro and ex vivo study of the antioxidant activity of carrageenans - sulfated polysaccharides of red algae]. Byull eksp biol i med. 2010;10: 398-401. Russian.

39. Krynytska I, Marushchak M. The indices of nitric oxide system in rats with carrageenan-induced enterocolitis combined with diabetes mellitus. Romanian Journal of Diabetes Nutrition and Metabolic Diseases. 2018;25(3): 283-8.

40. Krynytska I, Marushchak M, Svan O, Akimova V, Mazur L, Habor $\mathrm{H}$. The indices of endogenous intoxication in rats with carrageenan solution consumption. Georgian Medical News. 2018;279: 196-200.

41. Tkachenko AC, Gorbach TV, Ponomarenko OM. [Features of the protein spectrum and cytokine composition of rat serum in chronic carrageenan-induced intestinal inflammation]. Aktualni pytannia farmatsevtychnoi i medychnoi nauky ta praktyky. 2014;1(14): 73-5. Ukrainian.

42. Gubina-Vakyulyk GI, Tkachenko A, Gorbach TV, Tkachenko MO. Damage and regeneration of small intestinal enterocytes under the influence of carrageenan induces chronic enteritis. Comparative Clinical Pathology. 2015;24(6): 1473-7.

43. Bhattacharyya S, Dudeja PK, Tobacman JK. Carrageenan-induced NF kappa B activation depends on distinct pathways mediated by reactive oxygen species and Hsp27 or by Bcl10. Biochim Biophys Acta. 2008;1780(7-8): 973-82.

44. Kopanitsa OM, Marushchak MI, Shcherbaty AA. [Metabolic processes in the wall of the small intestine, heart and liver in the experimental use of carrageenan]. Medychna ta klinichna khimiia. 2017;3(72): 108-13. Ukrainian.

45. Marushchak MI, Kopanitsa OM, Krynytska IYa, Yaroshenko TY. [Peroxidation of proteins of the small intestine wall, myocardium, and rat liver with experimental use of carrageenan]. Medychna ta klinichna khimiia. 2017;4(73): 109-14. Ukrainian. 